\title{
On the Ambiguity of Obligatory Control into the tolok-Clause in Korean
}

\section{Introduction}

\author{
Jong Un Park | Georgetown University
}

One of the ways to express control dependency between a matrix object and a lower subject in Korean is to embed a clause headed by the marker -tolok (roughly translated as 'so that,' 'to the effect that,' or 'until'). What looks like a controller in control sentences subordinating the tolok-clause can be marked with ACCUSATIVE or NOMINATIVE Case, as in (1) and (2), respectively.

(1) John-un Mary-lul ttena-tolok seltukhay-ss-ta.

John-TOP Mary-ACC leave-COMP persuade-PAST-DECL

'John persuaded Mary to leave.'

(2) John-un Mary-ka ttena-tolok seltukhay-ss-ta.

John-TOP Mary-NOM leave-COMP persuade-PAST-DECL

'John persuaded Mary to leave.'

This paper aims to claim that the two sentences in (1) and (2) are instances of obligatory control, particularly the latter being an instance of backward control, and to show that clauses headed by the subordinator -tolok in other contexts are not the same as those in (1) and (2) in their syntactic nature and semantic function. It is then suggested that various patterns of interpretation from sentences subordinating the tolok-clause cannot be explained by any theory of control insisting that controlled subjects be uniformly an A-trace (equivalent to PRO) or pro. Rather, to derive the observed interpretive patterns from the sentences at issue, this paper appeals to Hornstein's (2001) insight as to anaphors and pronouns: that is, referentially dependent elements are to be interpreted as anaphors (esp., A-traces/OC PRO) if A-movement can take place, but as pronouns (esp., pro/NOC PRO) elsewhere.

\section{Previous Approaches}

\subsection{MTC-based Approach: Monahan (2003)}

It has long been argued that sentences with the embedded tolok-clause are an instance of OC (Kim (1978, 1984), Yang (1985)). Recently, this view has been supported by Monahan's (2003) observation that the same sentences meet the standard diagnostics for the OC properties (from Williams (1980) and Hornstein (2001)). Furthermore, Monahan (2003) convincingly shows that Case alternations found in the OC sentences with the tolok-complement can be better explained by the Movement Theory of Control (MTC, Hornstein (1999, 2001)) than the standard PRO Theory of Control (Chomsky (1981), Chomsky and Lasnik (1993)). Monahan suggests that the controller moves out of the tolok-clause leaving a copy, as in (3), and that FC is obtained by deleting a lower copy, as in (4a), while BC is made possible by eliminating a higher copy, as in (4b).

$$
\begin{array}{llrl} 
& \text { A-MOVEMENT } & \\
\text { John-un } & \text { Mary } & \text { [Mary ttena-tolok] } & \text { seltukhay-ss-ta. } \\
\text { John-TOP } & \text { Mary-ACC } & \text { leave-COMP } & \text { persuade-PAST-DECL }
\end{array}
$$

'John persuaded Mary to leave.'
a. FORWARD CONTROL (FC)
$(=(1))$
John-un Mary-lul [Mary-ka ttena-tolok]
John-TOP Mary-ACC Mary-NOM leave-COMP
seltukhay-ss-ta.
b. BACKWARD CONTROL (BC) (= (2))
John-un Mary-lul [Mary-ka ttena-tolok]
John-TOP Mary-NOM Mary-NOM leave-COMP
persuade-PAST-DECL
seltukhay-ss-ta.
persuade-PAST-DECL

\subsection{Semantic Approach: Cormack and Smith (2004), Choe (2006)}


Against the MTC-based approach, it is argued that sentences with the tolok-clause in Korean have little to do with OC. They instead suggest that null arguments are neither PRO nor an A-trace but pro, and their referential dependency with another argument in the matrix clause is either specified in meaning postulates (Cormack and Smith (2004)) or is subject to syntactic or pragmatic binding principles in Reinhart's (1981) sense (Choe (2006)). Although details are different, they basically suggest that the FC case in (1) is reinterpreted as (5), while the BC case in (2) involves two-step derivations in (6) and (7). Notice that since the null argument in the matrix clause in the BC case is assumed to be pro, the Rexpression Mary-NOM in the tolok-clause is likely to be bound by the c-commanding pro, which would incorrectly trigger Condition $C$ effects, as in (6). In order to avoid this problem, they stipulate that the tolok-clause must be scrambled across the c-commanding pro, as in (7).

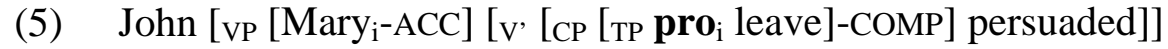

(6) Initial representation

*John [vp [pro ${ }_{\mathrm{i}}$ ] [v, [ст [тр Mary ${ }_{\mathrm{i}}$-NOM leave]-COMP] persuaded]] $\uparrow$ C-COMMAND

(7) After scrambling

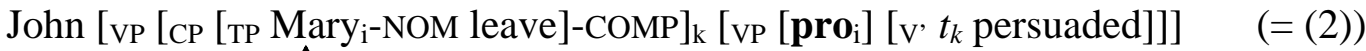

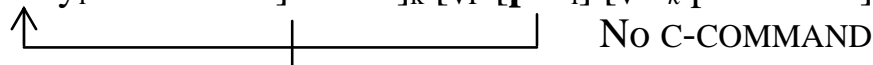

$(=(1))$

However, their approach encounters some problems. First, scrambling of the tolok-clause is not satisfactorily motivated, and it seems difficult to account for why a bound variable reading is available in sentences like (8). Second, the meaning postulates require the controller to be referentially dependent on an argument with an agent role, so an additional assumption needs to be made to explain the contrast between (9a) and (9b) regarding the controllee's thematic role.

John-un $\quad\left[\text { pro }_{\mathrm{i}} \text { ttena-tolok }\right]_{\mathrm{k}}$ nwukwu $\mathrm{i}_{\mathrm{i}}$-lul $t_{\mathrm{k}}$

John-TOP leave-COMP someone-ACC

'Who is x such that John persuaded x that x would leave?' (cf. Choe (2006: (36a))

\begin{tabular}{|c|c|c|c|c|c|}
\hline \multirow{2}{*}{\multicolumn{6}{|c|}{ int $^{\mathrm{h}}$ ebywu }} \\
\hline & & Sue-lul & int $^{\mathrm{h}}$ ebywu & ha-tolok & seltukhayss \\
\hline John-TOP & Mary-NOM/ACC & Sue-ACC & interview & do-COMP & persuaded \\
\hline \multicolumn{4}{|c|}{ 'John persuaded Mary ${ }_{i} \mathrm{PRO}_{\mathrm{i}}$ to interview Sue].' } & \multicolumn{2}{|c|}{$($ Controllee $=$ AGENT $)$} \\
\hline b. John-un & Sue-ka/lul & Mary-eykey & int $^{\mathrm{h}}$ ebywu & pat-tolok & seltukhaysst \\
\hline John-TOP & Sue-NOM/ACC I & Mary-DAT & interview & pass-COMI & persuaded \\
\hline
\end{tabular}

\subsection{Tolok-clauses in OC and causatives pattern alike: Kim (1995), Madigan (2008)}

It has also been claimed, as an alternative to the MTC-based approach, that the construction under discussion can be assimilated to the syntactic causative construction in (10), in that both constructions give rise to a causative-like reading and allow the controller/causer to take different case forms, as in (1), (2) and (10). In particular, Kim (1995) proposes that the null subjects in both constructions are pro, while Madigan (2008) comments on the categorial status of only the null subjects of the OC construction, taking them to be PRO.

(10) Syntactic CAUSATIVE

$\begin{array}{llll}\text { John-un } & \text { Mary-ka/lul/eykey } & \text { ttena-tolok/key } & \text { hay-ss-ta. } \\ \text { John-TOP } & \text { Mary-NOM/ACC/DAT } & \text { leave-COMP/COMP } & \text { do-PAST-DECL }\end{array}$

'John made Mary leave.'

However, this kind of unified approach seems to run into some problems. First, a causal relation in the OC construction appears to be weaker than the one in the syntactic causative construction, although there is speaker variation. Second, the two constructions exhibit different results when the 
matrix verb is immediately preceded by a manner adverb, or when some syntactic operations apply (relevant examples omitted due to space limitation).

\section{Proposed Analysis}

Although Monahan's (2003) approach, which adopts the MTC at face value, appears to be on the right track in capturing exhaustive control (EC, in Landau's (1999) sense), it has been reported in the literature that control sentences with the tolok-clause permit other readings than EC, as in (11) (from Kim (1995: (167), p.247) with some modification).

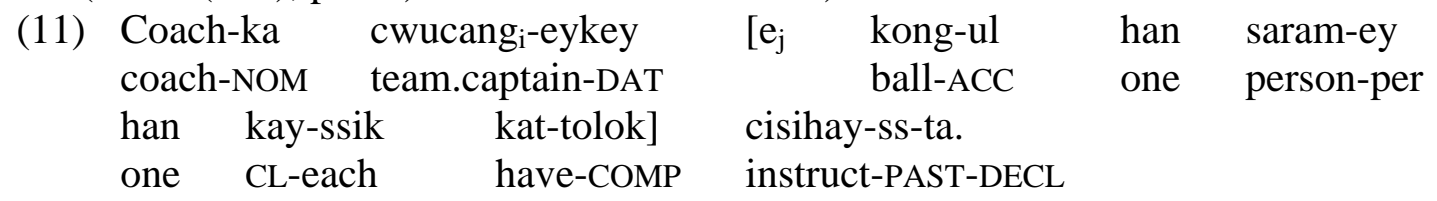

'The coach instructed the team captain that (the players) have one ball per person.'

In order to explain various interpretive patterns like this, this paper adopts Hornstein's (2001: Ch 2) idea for interpreting referentially dependent elements. At the heart of Hornstein's idea is the following disjunctive mechanism for assigning references to anaphoric arguments:

(12) a. Environments where OC is possible are those where A-movement of a controller can take place, and OC PRO can be reinterpreted as an A-trace.

b. Environments where NOC is possible are those where A-movement of a potential antecedent cannot apply, and NOC PRO need to be reanalyzed as pro.

Building on this mechanism, I suggest that there is more than one tolok-clause in Korean, which can be a complement or an adjunct depending on the syntactic environment they appear. As comprehensively discussed in Suh (1996: Ch 22), tolok is normally defined as a subordinator of a clause that (i) denotes a purpose of the matrix event; (ii) expresses a result or degree of resulting state of the matrix event; or (iii) indicates the temporal end point of the matrix event, and so forth (illustration of relevant data precluded due to space reason). It is thus not surprising that the clause headed by the subordinator -tolok is found not only in OC and causative constructions, but also in various other contexts, such as resultatives, where the tolok-clauses can be diagnosed as adjuncts (cf. Shim and den Dikken (2009) for an analysis of the tolok-clauses as adjuncts in subject-oriented resultatives in Korean).

These facts also lead me to argue that the tolok-clauses with OC readings accompanied are complements, while those without are unselected adjuncts. Pieces of evidence in favor of this argument can be easily found. For instance, sentence (11) can be paraphrased as (13), and given that the maximum valency of control predicates is 'three,' it follows that the tolok-clause in this context should be an adjunct (cf. Kim (1995: 249-250) for a similar argument).

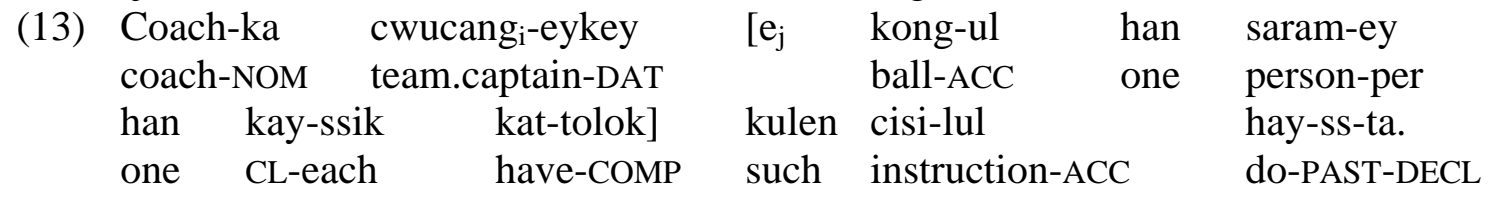

'The coach gave an instruction to the team captain so that (the players) have one ball per person.'

Now we are left with a question about the categorial status of null subjects in the tolok-clauses that are analyzed as adjuncts here, thereby lacking the obligatory referential dependency. Given that Amovement (except scrambling) out of the adjunct is not allowed, it immediately follows that they are not A-traces but pro. One piece of evidence comes from the fact that (i) overt pronouns can be substituted for null subjects and (ii) NOMINATIVE Case is assigned, as in (14). 

(14) Cokyo-ka
[haksayng-tul-i
te
teacher's aid-NOM
student-PL-NOM
more
umak swuep-ul
tut-tolok]
hakpwumo-lul
seltukhayssta.
parent-ACC
persuaded
'The teacher's aid persuaded the parents that their children should take more music lessons.'
Polinsky et al. (2007: (27))

Second, the sentences with the tolok-clause triggering OC do not allow the multiple occurrences of floating quantifiers, while those with the tolok-clause with NOC permit them ((15) adapted from Hornstein (2001)).
a. ??John-un pwumotul
motwu-lul $\left[t_{i}\right.$
kakak ttena-tolok]
seltukhayssta.
John-TOP parents
all-ACC
each leave-COMP
Intended: 'John persuaded the parents all to each leave.'

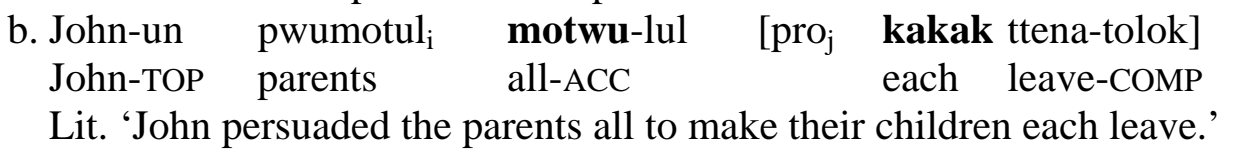
c. ??John-un pwumotul $\mathrm{i}_{\mathrm{i}}$ motwu-lul $\left[t_{i}\right.$ motwu ttena-tolok $]$
John-TOP parents all-ACC all leave-COMP
Intended: 'John persuaded the parents all to all leave.'
d. John-un pwumotul motwu-lul $\quad\left[\mathrm{pro}_{\mathrm{j}}\right.$
John-TOP parents
all-ACC
motwu ttena-tolok]
all leave-COMP
Lit. 'John persuaded the parents all to make their children all leave.'
persuaded
(OC)
seltukhayssta.
persuaded
(NOC)
seltukhayssta.
persuaded
(OC)
seltukhayssta.
persuaded
(NOC)

\section{Conclusion}

This paper has shown that the ambiguity found in control sentences with tolok-clauses in Korean can be attributed to the various usages of the subordinator -tolok. In particular, I have argued that we need to distinguish between the tolok-clauses triggering OC and those yielding NOC in terms of their categorial status - the former being complements, while the latter being adjuncts. This being said, since there is nothing that prevents the controller from undergoing A-movement in (1) and (2), these sentences can be characterized as OC, the former being defined as forward control while the latter as backward control. This in turn leads us to conclude that no approaches insisting that null subjects in the tolok-clauses embedded under control predicates be invariably an A-trace, PRO or pro, can be entirely correct.

\section{Selected References}

Choe, Hyon-Sook. 2006. On (Backward) Object Control in Korean. In S. Kuno et al. (eds.), Harvard Studies in Korean Linguistics XI, 373-86. Cambridge, MA: Harvard University.

Hornstein, Norbert. 2001. Move! A Minimalist Theory of Construal. Malden, MA: Blackwell Publishers. Kim, Kyungan. 1995. Casuativity in Korean: Syntactic Causative, Control and Purpose. Doctoral Dissertation, University of Southern California.

Landau, Idan. 1999. Elements of Control. Doctoral Dissertation, MIT.

Madigan, Sean. 2008. Control Constructions in Korean. Doctoral Dissertation, University of Delaware. Monahan, Philip. 2003. Backward Object Control in Korean. In G. Garding and M. Tsujimura (eds.), WCCFL 22 Proceedings, 356-369. Somerville, MA: Cascadilla Press.

Polinsky, Maria, Philip Monahan and Nayoung Kwon. 2007. Object Control in Korean: How Many Constructions?” Language Research 43.1, 1-33.

Shim, Ji Young and Marcel den Dikken. 2009. The Tense of Resultatives: The Case of Korean. To appear in the Proceedings of NELS 38. Amherst, MA: GLSA.

Suh, Jeong Soo. 1996. The Korean Grammar. [written in Korean] Seoul: Hanyang University Press. 